\title{
Secondary School Students' Perceptions of, and the Factors Influencing Their Decision- Making in Relation to, VET in Schools
}

\author{
Leanne Dalley-Trim \\ Nola Alloway \\ Karen Walker \\ James Cook University
}

\begin{abstract}
This paper addresses the issue of Vocational Education and Training in Schools - an issue that has recently attracted significant political attention particularly in light of current national skills shortage in Australia. Specifically, it investigates secondary school students' perceptions of VET in Schools [VETiS]. It also explores the factors influencing their decision-making in relation to VETiS - that is, why one might choose, or choose not, to enrol in a VETiS course of study. In view of the findings presented, the paper argues that VET, and more particularly VETiS, is experiencing an "image problem" - one underscored by the need for curriculum design and delivery reform - and suggests that there is much work still to be done on the VET agenda.
\end{abstract}

\section{Introduction}

This paper explores the issue of VET in Schools [VETiS] and extends work reported elsewhere (Walker, Alloway, Dalley-Trim, \& Patterson, 2006). Drawing upon a national Australian study and data derived from interviews conducted with students during the course of the research, it focuses upon secondary school students' perceptions of, and the factors influencing their decision-making in relation to, VETiS. Specifically, it examines the ways in which students' perceive VETiS, its place within the curriculum and those who do VETiS. It provides insight into the reasons why students chose to, or chose not to, enrol in VET while at school. Finally, it aligns student perceptions with the image problem currently confronting the VETiS agenda. 


\section{VET in Schools}

Vocational Education and Training, and Vocational Education in Schools more particularly, have found themselves in the political spotlight in recent times, in part, as a result of the current national skills shortage in Australia. Indeed, it is the case that considerable focus has been placed upon VETiS within the last decade and in line with this increased focus has come increasing research - and increasingly substantial formal research - into the area (see Anlezark, Karmel, \& Ong, 2006; Barnett \& Ryan, 2005; Porter, 2006; Ryan, 1997).

The current definition of VETiS, adopted in 1999 by the Ministerial Council for Education, Employment, Training and Youth Affairs, is as follows: "VET in Schools programs are undertaken as part of a student's senior secondary certificate and provide credit towards a nationally recognised VET qualification. VET in Schools programs are based on national industry competency standards" (Ministerial Council on Employment, Education, Training and Youth Affairs Transition from School Taskforce, 2004; National Centre for Vocational Education Research (NCVER), 2007).

There are two main avenues for participating in VETiS - firstly, through "course or subject programs, commonly referred to as "VET in Schools programs" (Nguyen, 2005, p. 41), and secondly, through school-based New Apprenticeships. It is upon the first of these two options that this paper focuses - to the exclusion of the second.

Research indicates an increase in student participation in VETiS and a commensurate increase in the number of schools offering VETiS programs within Australia. In 2003, 202,900 students were enrolled in VETiS; in 2002, 185,500 students were enrolled; in 2001, 170,000 students were enrolled; in 1998, 117,000 were enrolled, and in 1996, 60,000 students were enrolled in VETiS (Barnett \& Ryan, 2005; Nguyen, 2005). Such data indicate an increase from $16 \%$ to $44 \%$ in the proportion of senior secondary students undertaking VET in Schools programs (Australian National Training Authority, 2002; Barnett \& Ryan, 2005). The number of schools offering VETiS programs increased from $70 \%$ in 1997 to $95 \%$ in 2001 (Australian National Training Authority, 2002, p. 19). Of these schools, it is reported that $60 \%$ are government schools (The Department of Education, Science and Training, 2002, p. 54).

Research has also provided insight into the profile - or identifying characteristics - of students who do VETiS. Work undertaken by the Australian Council for Educational Research (2002) suggests that VETiS programs attract low-achieving students, those from English speaking backgrounds, those residing in rural areas, those attending government schools and those whose parents did not have a tertiary education. Students from low socio-economic backgrounds are also more likely to participate in these programs (Polesel et al., 2003), and these students are also less likely to apply 
to university than their non-vocational peers (Polesel, 2001). A significantly smaller proportion of high achievers (13\% in 2002) also take part in VETiS programs (Department of Education, Science and Training, 2002). Further, almost equal numbers of male and female students are represented in VETiS enrolment figures, and students are typically in Years 11 and 12 when undertaking VETiS programs (NCVER, 2002; Nguyen, 2005).

Research into students' perceptions of VETiS and the factors influencing their reasons for pursuing, or not pursuing, VET pathways while in secondary school has until quite recently been limited. Three recent studies have explored these issues: "School Students Making Education and Career Decisions: Aspirations, Attitudes and Influences" (Alloway, Dalley, Patterson, Walker, \& Lenoy, 2004) - as drawn upon in this paper; "Survey of Vocational and Technical Education (VTE): Participation, Triggers, Perceptions and Aspirations" (Department of Education, Science and Training, 2005) and "What Makes Vocational Training Programs in Schools Work? A Study of New South Wales and Queensland Schools" (Porter, 2006). A selection of findings from DEST and Porter's research, as pertinent to this paper, are provided here - and as evidenced, bear striking consistency with, and thus add further weight to, the findings of the national study (Alloway et al., 2004) under discussion here.

The "Survey of Vocational and Technical Education (VTE): Participation, Triggers, Perceptions and Aspirations" (Department of Education, Science and Training, 2005, p. 13) reported that current secondary students aged 15-19 years identified the following as triggers to participation in VTE: "future job opportunities" (81\%), "a recognised qualification" (73.1\%) and "interesting subjects" (77.3\%). Further, they reported that these 62 percent of students perceived that "VTE is good for people who aren't suited to academic careers" (Department of Education, Science and Training, 2005, p. 19).

Porter (2006) reported that students identified three key themes in relation to the selection of VET subjects: personal reasons, future aspirations and limited choices.

Personal reasons included: students found VET subjects interesting, were good at them, liked them and preferred practical subjects as they were more "hands on" and were perceived to be more suited to their academic ability.

Factors relating to future aspirations included: VET subjects allowed experimentation of career paths and informed decisions on future careers and could offer a head start in a chosen job or career.

Factors that limited choices included: restrictions due to timetabling of VET subjects, the selection or admissions criteria of schools and tertiary institutions, and the availability of school resources. (Porter, pp. 17-18) 
Porter (2006, p. 18) noted, "while qualifications were perceived as highly valued ... students had difficulty articulating the name of their VET course, as well as the expected final qualification". Students viewed VET as offering them a head start and that the work placement component of VET subjects provided them with "an opportunity to 'make a heap of contacts' for the future" (Porter, p. 18). Further, "students liked doing [the] practical activities" associated with VET programs (Porter, p. 19).

In terms of the disadvantages in relation to the undertaking of VET courses, the main issues cited by the stakeholders - not only students - pertained to: "the difficulties associated with missing lessons due to VET activities; the loss of a tertiary entrance score/index/rank/position [and] the negative perceptions about VET and VET students" (Porter, 2006, p. 20). Interestingly, and at odds with the findings of the Alloway et al. (2004) study, Porter notes in reference to the final point, "any stigma attached to VET subjects was not explicitly mentioned by students in government schools" (Porter, p. 20).

In relation to this issue of the stigma associated with VET, and the negative perceptions of both VET and the students who participate in VET, it is essentially the case that VET has been seen to be a "soft" option and of low status. Ryan, in 1997, noted "vocational education remains limited by the conception that it is for lower achieving students" (p. 19). More recently, Barnett and Ryan (2005, p. 7) claimed "the largest issue for students ... is the marginalisation of VET programs and the status of VET courses." Nonetheless, they suggest that a shift may have occurred in schools in terms of the cultural attitudes towards VETiS (Barnett \& Ryan, 2005; see also Porter, 2006).

\section{Methodology}

This paper draws upon findings of the national study, "School Students Making Education and Career Decisions: Aspirations, Attitudes and Influences" (Alloway et al., 2004) - a DEST contracted and funded project that investigated five key issues: education and career decision-making processes, career advisers and career information services in schools, Vocational Education and Training in Schools [VETiS], traditional trades as a career and teaching as a career. It is upon the third of these issues, Vocational Education and Training in Schools, that this paper focuses.

In undertaking the original study, qualitative data were collected by a team of researchers. Interview protocols, consistent with semi-structured interviews, were developed and utilised by the researchers. 
In relation to the issue of VETiS, the following interview protocols were addressed:

- Over the past few years, many schools across Australia have introduced vocational education and training into the school curriculum. What do you know about studying VET subjects at school?

- Have you decided to include any VET subjects in your course of study next year? Why? Why not?

- When students choose VET subjects, what are they trying to achieve?

- What do other students at this school think about studying VET subjects at school?

- Would you consider applying for a school-based apprenticeship? Why? Why not?

Focus group interviews were conducted with Years 10 and 12 students in public secondary schools in three Australian states - Queensland, Western Australia and New South Wales - and with parents in each of the three New South Wales schools, where the research effort was concentrated. Interviews were also conducted - at times individually and other times in pairs - with career advisers or like staff and with principals and deputy principals in each of the schools.

Within each state, school sites were selected to represent a range of socio-economic (upper, middle and lower) and geographical (metropolitan and rural) demographic diversity across Australia. The SES categorisation of individual school sites was determined in consultation with the various state education departments each of which had a system in place that ranked schools according to numerous variables. Table 1 details the SES and geographic locations of school sites visited.

Of relevance to this paper were the interviews conducted with students, which as signalled above, were conducted with students in Years 10 and 12 in each of the school sites. With a view to capture gender-differentiated data, students were grouped according to gender in addition to year level. In the New South Wales schools, student focus groups were further

\begin{tabular}{|c|c|}
\hline $\begin{array}{l}\text { SES and Location } \\
\text { of School Sites }\end{array}$ & $\begin{array}{c}\text { Number } \\
\text { of School Sites }\end{array}$ \\
\hline Urban Lower SES & 3 \\
\hline WA & 1 \\
\hline QLD & 1 \\
\hline NSW & 1 \\
\hline Urban Middle SES & 3 \\
\hline WA & 1 \\
\hline QLD & 1 \\
\hline NSW & 1 \\
\hline Urban Upper SES & 2 \\
\hline QLD & 1 \\
\hline NSW & 1 \\
\hline Rural & 1 \\
\hline NSW & 1 \\
\hline Total & 9 \\
\hline \multicolumn{2}{|c|}{$\begin{array}{l}\text { Table 1: Socio-economic and } \\
\text { Geographical Demographic } \\
\text { of Participating Schools }\end{array}$} \\
\hline
\end{tabular}


differentiated and formed in relation to whether students were considered to be "academic" or "non-academic". The grouping academic/non-academic relied on teachers' knowledge of students' subject selections and, to a lesser extent, on teachers' perceptions of students' aspirations for the future. In total, 340 students were interviewed. Table 2 provides details of the student interviews conducted.

\begin{tabular}{|c|c|c|}
\hline School & Boys & Girls \\
\hline Upper SES & 44 & 42 \\
\hline Middle SES & 6 & 44 \\
\hline Lower SES & 48 & 56 \\
\hline Rural & 27 & 33 \\
\hline Total (340) & 165 & 175 \\
\hline
\end{tabular}

Table 2: Students Interviewed in Schools

In relation to the New South Wales schools, staff were informed that the request for academic/non-academic groupings of students did not mean that they were to select student groups on the basis of achievement. That is, students' inclusion in the groups did not have to correlate with their report cards. Rather, the groups that were named as academic were to be comprised of students who generally had chosen subjects that supported an academic/tertiary/professional career pathway. They might include, for instance, students who were attempting advanced or extension levels of Mathematics or English. Some of the students included in this group might well be straight A students, but it might also include students who had chosen an academic subject stream but found it to be a struggle. Students who had adopted this stream might also have included other studies including VETiS. The groups that were named as nonacademic would be comprised of students who had generally chosen subjects that supported a clearer pathway to a career through TAFE, vocational training, or a trade. Again, a correlation with low or poor achievement was not to be the guide for inclusion in the focus group. The group might include students who were quite capable of success in academic courses but chose more vocationally oriented subject streams because of the interests that they held and the outcomes to which they aspired. It might also include students who were known to have struggled with more challenging academic studies (See Table 3 for details).

\section{Investigating Student Insights}

The findings of this study (Alloway et al., 2004) illuminate Australian students' perceptions of VETiS - its merits and limitations - and its place within the curriculum, and of those students who do VETiS. They provide insight into the reasons why students chose to, or chose not to, enrol in VET in Schools and/or participate in a VET pathway while at secondary school. 


\begin{tabular}{|c|c|c|c|c|}
\hline Year Level & $\begin{array}{c}\text { Academic } \\
\text { Boys }\end{array}$ & $\begin{array}{c}\text { Non-Academic } \\
\text { Boys }\end{array}$ & $\begin{array}{l}\text { Academic } \\
\text { Girls }\end{array}$ & $\begin{array}{c}\text { Non-Academic } \\
\text { Girls }\end{array}$ \\
\hline \multicolumn{5}{|c|}{ Students in Upper SES School } \\
\hline 10 & 9 & 7 & 8 & 8 \\
\hline 12 & 8 & 8 & 8 & 7 \\
\hline \multicolumn{5}{|c|}{ Students in Middle SES School } \\
\hline 10 & 8 & 5 & 6 & 9 \\
\hline 12 & 6 & 7 & 2 & 6 \\
\hline \multicolumn{5}{|c|}{ Students in Lower SES School } \\
\hline 10 & 4 & 5 & 8 & 7 \\
\hline 12 & 5 & 6 & 5 & 7 \\
\hline \multicolumn{5}{|c|}{ Students in Rural School } \\
\hline 10 & 6 & 9 & 9 & 9 \\
\hline 12 & 5 & 7 & 8 & 7 \\
\hline
\end{tabular}

Table 3: Students Interviewed in New South Wales Schools - Academic/Non-Academic

\section{What is VET?}

"What is VET?" and "Which are the VET subjects?" were questions directed by students to the researchers during the course of interview. It became evident that for many of the students VET was somewhat of an unknown quantity - even for those students who, as it emerged in interview, were enrolled in VET subjects.

While many students demonstrated a lack of familiarity with the term "VET", when the concept was explained, or "named", they were able to make connections.

S: I knew you could do school subjects with TAFE courses, but I never knew that was called VET education.

S: We know what it is, but we, I didn't know that it was all of that.

I: Vocational Education and Training.

S: You guys only know because you're actually doing it!

S: We've been hearing about it, but it's like "OK, that's cool, you can do it - OK, it's got a name!"

(Year 12 Non-Academic Females - Upper SES)

Additionally, the students, and particularly those undertaking VET subjects, were able to identify that which constitutes VET by citing a range of subjects - rather than by making reference to the concept of Vocational Education and Training as identified by the acronym VET. 
For many of the students, particularly those in the State of New South Wales, VET was clearly aligned to TAFE (i.e., Technical and Further Education Colleges). This was the case despite the fact that many of the students studied VET subjects at school. It clearly remained, from their perspective, within the domain of TAFE colleges and was not referred to in terms of "VET in Schools".

S: We're doing a T-VET course where we're going to do it at TAFE.

(Year 10 Non-Academic Female - Lower SES)

S: T-VET. It's basically the TAFE version of it.

(Year 12 Non-Academic Female - Rural)

It became apparent that students, encompassing all geographical, gender and SES demographics, had a limited understanding of the "formalised" terminology of Vocational Education and Training. This could, in part, be accounted for by the undifferentiated language practices employed by staff in many of the schools visited. That is, the school staff interviewed, spoke of using non-specific language when referring to school subjects and/or courses, and of employing a broad-based curriculum approach rather than a more differentiated (i.e., VET/non-VET) one. It was the case that while the range of subject offerings were broadened to include VET subjects, students were often not made explicitly aware of differences between VET and other subjects offered within their schools. Such practice on the part of school staff often led to confusion among students - whose comments indicated that they were unsure of whether or not they had enrolled in VET subjects:

S: I do a VET course but I really don't know the difference.

(Year 12 Academic Male - Middle SES)

S: We chose it without knowing it was a VET course.

(Year 12 Non-Academic Female - Middle SES)

While this practice of non-differentiation was common, students' limited understanding of VETiS may also signal that many students are often not well informed about VET when making decisions about subject selection and the pathways available to them at secondary school. In this event, it appears that work needs to be done in schools to better educate students about VET and the opportunities it provides students in school and beyond since the consequences of not having access to accurate information about subject selection could be far reaching.

\section{Why do VET?}

When discussing the reasons why one might chose to enrol in VET subjects, the students identified a number of positive features of VET, and offered a number of perceived advantages of enrolling in VETiS. They suggested that VET subjects were 
the "good" subjects, the enjoyable subjects. They suggested, too, that VET subjects provided valuable qualifications and a "head start" in terms of post-school pursuits. Additionally, they perceived VETiS to provide welcome relief from the more taxing demands of academic subjects.

The fun factor The students - within all three States - placed significant emphasis on the view that VETiS subjects were the "enjoyable", "fun" and "exciting" subjects. They compared VET subjects with, and positioned them as oppositional to, the "normal", "boring" school subjects. VET subjects were, they suggested, "different from" the normal school subjects on offer and were more "practical" in nature.

S: [VET is] something new and exciting.

(Year 10 Non-Academic Female - Rural)

S: [It's] something different from Maths and English and some stuff like that.

(Year 10 Non-Academic Male - Lower SES)

S: It's just a fun course to do. It's different from sitting there in a boring classroom - because you're out doing things, you're practical.

(Year 12 Non-Academic Female - Lower SES)

S: [VET] helps you more because you are doing more practical stuff instead of sitting in a class and listening constantly, writing and talking your ears off.

(Year 12 Female - Middle SES)

A ticket to ride VET was seen to provide students with a head start and to function "like stepping stones" for students in their future lives. It was perceived to provide students with prized qualifications, to offer vital links to TAFE pathways, and to provide opportunities to gain valuable "life skills" including those that would lead directly to employment. So, too, was VET seen to serve as a "back up", as providing qualifications and vocational experiences that students could "fall back on".

S: Some of them [i.e., VET subjects/courses] give you qualifications and some of them get you on your way.

(Year 12 Female - Middle SES)

S: I think it's [VET] a good idea. It allows people who want to do a specific career path to start now and go on work experience and have that on their resume.

(Year 12 Female - Middle SES) 
S: I want knowledge to put behind me so that I can go to someone and say, "Give me a job." If they go, "Have you got any experience?" - and I can go, "Yes. Try two certificates for the T-VET, my HSC certificate and my college certificate or Uni."

(Year 12 Non-Academic Male - Lower SES)

A change of pace VET was also seen as offering many of the students - and in particular the male students - a change of pace in their study program. Viewed by career advisers and students alike as "less intellectually demanding" and "less emotionally stressful", VET subjects were more likely taken for enjoyment and as a break from a more rigorous academic load than for any other reason identified by the students. This view was typified in interview with a group of Year 10 non-academic males from a lower SES school when they were questioned as to why students would choose to enrol in a VET subject:

S: Maybe because they enjoy it.

S: Something different.

I: Something different?

S: Something different from Maths and English and some stuff like that.

S: Might be a bit of a break, something they can relax ...

S: They're doing what they want to do.

$\cdots$

S: Or it might be just like a break subject - something they can just relax in - not got stressed. ..

S: You're not exactly stressed about it.

S: Yeah, you're enjoying yourself.

S: Yes.

While viewed in this way by students and staff alike, it is argued here that such a perception is potentially problematic. That is, it operates in such a way as to tap into the binary constructs of academic/non-academic and "intellectual/practical" - and in this way, may well work towards perpetuating the presently conceived low status of VETiS (Dalley-Trim, Alloway, Patterson \& Walker, 2007; see also Stevenson, 2000 for a detailed theoretical discussion). 


\section{Why not do VET?}

While, as discussed above, the students perceived there to be benefits of enrolling in a VET subject and/or course while at school, they also offered reasons as to why one might choose not to undertake VETiS studies. There was, in essence, a broad voicing of negative perceptions, experiences and suspicion of VET subjects, and this was evident across all schools, among all SES groups and for male and female students. The key reason identified by students for not enrolling in VETiS centred on the issue of the status of VET. More specifically, the status of VET as aligned to which type of student was suited for - and subsequently enrolled in - VET, the nature of VET subjects, and the link between VET and university entrance scores.

\section{Those who can't, do VET}

VET was clearly marked as the domain of the non-academic student - there was seemingly no question about it. VET was the pathway to which the non-academically oriented student was destined - the "lot" of such a student. In relation to this, VET was for the non-academic "doers" of physical and undervalued work, while in contrast, non-VET subjects were for the doers of valued and mentally rigorous work.

The academic students particularly were quite clear that VET was the pathway to be pursued by their non-academic peers and not themselves.

S: People don't recommend it if you're like an achiever.

(Year 10 Academic Male - Middle SES)

S: They [i.e., those who do VET] don't do well in academic subjects. (Year 10 Academic Male - Rural)

S: Basically, if you don't want an OP job or if you don't have any aspirations for a uni-based career ... they just go for VET subjects because they can't be bothered studying.

(Year 12 Female - Middle SES)

As these comments reflect, VETiS was de-valued as were the students who participated in it.

In line with such devaluation of VET and the students who participated in VETiS programs, VET was also seen to be the "dumping ground" for "troublemakers". In this way, the status of VET was further called into question and scrutinised. One student, for example, claimed that one of his teachers warned good students off doing VET, stating: "It's only for bad people, because $\mathrm{Mr} \mathrm{X}$ said if you go ask him he won't put you in it. ... You do it to get on discipline and stuff like that" (Year 10 Male - Lower SES). As this example illustrates, some teachers, too, seemingly become complicit in the devaluing of VET as a viable pathway for good students. 
The devaluing and demeaning of students - the non-academically oriented students - who participated in VETiS was prevalent. These students were labelled and referred to as "drop-kicks", "drop-outs" and "bludgers". A group of Year 10 academic males, for example, suggested that these students were looked upon and treated "differently" largely because they "couldn't do the hard yards" involved with "getting into University". These students also suggested that people viewed those students doing VETiS as "lower" and as "not so good." One of them also spoke of family members "warning them off" associating with these particular students, suggesting: "And sometimes family might tell you, 'Don't hang around that sort of person' or that, 'cause you might pick up some of their ways or something'". Tellingly, the nonacademic students - and specifically the non-academic males - also spoke in these derogatory terms, labelling themselves and their VET-enrolled peers bludgers.

\section{A road to nowhere}

Like the students enrolled in VET, the subjects themselves were also devalued, scrutinised and viewed with suspicion. The students' spoke of VET subjects as being "a waste", "a waste of time"; and perceived them to be subjects that "won't get you anywhere". VET was seen to be "easier" - and thus devalued - because "they're courses that you can do without studying". As such, it is advocated here that there exists a clear need to re-examine, and indeed reform, the design and delivery of VET curricula in schools.

This perception of VET - its status and indeed usefulness - was also explicitly linked to the importance placed upon University entrance requirements: UAI (University Admission Index) in New South Wales, OP (Overall Position) in Queensland and TE (Tertiary Entrance Score) in Western Australia. The onus placed upon tertiary entrance, and the relationship between the perceptions of VET as futile and devalued, was evident in student comments. As one Year 10 female student, typifying student views, indicated: “... because you're like getting towards getting a good OP - there's no point in doing it [i.e., VET] - you may as well stay home".

Furthermore, VET was viewed with open suspicion by students in relation to its place within the curriculum generally, and more specifically in relation to tertiary-bound pathways. In relation to its place in the curriculum generally, students questioned whether or not VET was a "real" school course.

S: I think people are worried ... my point of view is I don't ... I can't say I really trust it [VET] because I ... you come to school to do school, and when you hear about other courses like that, you wonder about it, that it actually will still count the same, or if ... 
S: ... they [VET courses] just seemed, like they're not real school courses for me.

(Year 12 Non-Academic Males - Upper SES)

Signalling suspicion in relation to the place of VET in a tertiary-bound pathway, one student warned: "I don't think it wise to mix board and VET subjects" (Year 10 Female - Middle SES). Clearly, VET was viewed to be of little value, if not potentially dangerous, to the tertiary-bound student.

\section{Emergent Issues and Ways Forward}

VETiS is evidently experiencing an image problem. It appears that VETiS subjects remain the poor cousin of real school subjects and are perceived of as such by students. They remain, within the minds of students, outside of, oppositional to, and marginalised from, mainstream academic curriculum offerings. In line with - and arguably underpinning - this image problem, are issues pertaining to curriculum design and delivery of vocational education and training in schools; issues which appear to perpetuate the low status currently afforded to VETiS. So, too, does engagement by students (and indeed school staff) with the binary logic of knowledge/work, knowing/doing, theoretical/practical and academic/non-academic - binaries that seem apparent in the present design and delivery of vocational education curricula - serve to reinforce this standing of VETiS (Dalley-Trim et al., 2007; Stevenson, 2000).

While the students' provided reasons for doing VETiS, and in this way "positive" perceptions of it, closer analysis of two of these three key insights - referred to as "the fun factor" and "a change of pace" - may show them to be less innocuous than they first appear. It is suggested here that the perception of VETiS as being fun, different and more practical, and as providing a change of pace or "a break" in an otherwise rigorous academic load demanding "serious" attention and application on the part of students, serves in some way to "buy into" the diminished status commonly afforded VET. VET can be seen, in this way, as "other to" mainstream - serious, challenging and real curriculum offerings.

The students' insights into the reasons why one would choose not to enrol in VETiS and their negative perceptions of it sends a dire message and illuminates the image problem with which VETiS is confronted. These views, as expressed by the students, reaffirm previous warnings. For example, as Klee argued in 2002, "If VET is perceived as a dumping ground for academic failures and delivered as such . . . then it is doomed" (p. 53). Further, failure to reconcile the relationship between VETiS and tertiary entrance scores and procedures seems problematic at least in terms of the future possible take up by students of VETiS offerings. 
Further, in light of the confusion prevalent in students' comments, it is suggested that many students are often not - or not well - informed about VET when making decisions about subject selection and the pathways available to them at secondary school.

Evidently, there is much work yet to be done on the VET agenda - and on the image problem of VETiS in particular. Students need to be better informed in relation to VET pathways. So, too, do stakeholders responsible for generating and disseminating information to students need to readdress their current practices. An overhaul of current "marketing" strategies is urgently required. There is a clear need to "up the ante" in terms of promoting the merits of VETiS and to "tap into" the more productive of the positive perceptions of VET as espoused by the students here. It is imperative that existing storylines circulating about VET in the public sphere are disrupted and replaced by more positive and well-informed ones - those that pay due to the merits of Vocational Education and Training, and VETiS more particularly. Finally, there is an apparent need to re-think the ways in which VETiS curricula is designed and delivered - for this clearly underpins the points raised above.

\section{References}

Alloway, N., Dalley, L., Patterson, A., Walker, K., \& Lenoy, M. (2004). School students making education and career decisions: Aspirations, attitudes and influences. Canberra: Department of Education, Science and Training.

Anlezark, A., Karmel, T., \& Ong. K. (2006). Have school vocational education and training programs been successful? Adelaide: NCVER.

Australian Council for Educational Research. (2002). Vocational education and training: Participation, achievement and pathways. Longitudinal Surveys of Australian Youth (LSAY), Research briefing paper, 7. Melbourne: ACER.

Australian National Training Authority. (2002). Submission to the House of Representatives Standing Committee Inquiry into Vocational Education in Schools. Brisbane: ANTA.

Barnett, K., \& Ryan, R. (2005). Lessons and Challenges: Vocational Education in Schools - Research Overview. Adelaide: NCVER.

Dalley-Trim, L., Alloway, N., Patterson, A., \& Walker, K. (2007). Vocational education and training in schools: Career Advisers' perceptions and advising practices. Australian Journal of Career Development, 16 (1), 29-36.

Department of Education, Science and Training. (2002). Submission to the House of Representatives Standing Committee Inquiry into Vocational Education in Schools. Canberra: DEST.

Department of Education, Science and Training. (2005). Survey of vocational and technical education (VTE): Participation, triggers, perceptions and aspirations. Barton, ACT: DEST. 
Klee, C. (2002). A practitioner's view of vocational education and training in schools. Unicorn, 28 (3), 48-54.

Ministerial Council on Employment, Education, Training and Youth Affairs Transition From School Taskforce (2004). National data on participation in vet in schools programs and school-based new apprenticeships for 2003 school year. Canberra: MCEETYA.

National Centre for Vocational Education Research (NCVER). (2002). Submission to the House of Representatives standing committee inquiry into vocational education in schools. Adelaide: NCVER.

National Centre for Vocational Education Research (NCVER). (2007). Did you know? A guide to vocational education and training in Australia. Adelaide: NCVER.

Nguyen, N. (2005). Australian vocational education and training statistics: VET in schools 2003. In NCVER, Australian vocational education and training: Research messages 2004. Adelaide: NCVER.

Polesel, J. (2001). Vocational education and training in schools in Victoria: An appraisal six years down the track. Journal of Vocational Education and Training, 53 (2), 325-340.

Polesel, J., Helme, S., Davies, M., Teese, R., Nicholas, T., \& Vickers, M. (2003). VET in schools: Culture, policy and the employment and training impact. Adelaide: NCVER.

Porter, J. (2006). What makes vocational training programs in schools work? A study of New South Wales and Queensland schools. Adelaide: NCVER.

Ryan, R. (1997). Vocational education in schools. Adelaide: NCVER.

Stevenson, J. (2000). Working Knowledge. Journal of Vocational Education and Training, 52 (3), 503-519.

Walker, K., Alloway, N., Dalley-Trim, L., \& Patterson, A. (2006). Counsellor practices and student perspectives: Perceptions of career counselling in Australian secondary schools. Australian Journal of Career Development, 15 (1), 37-45. 